\title{
Validity Test of the Family Supported Collaborative Learning (FSCL) Model to Instill Character Values to Junior High School Students
}

\author{
Jauhan Budiwan*, Furqon Hidayatullah, Munawir Yusuf, Asrowi \\ Department of Doctoral Program, Faculty of Teacher Training and Education, Universitas Sebelas Maret, Indonesia
}

Received December 9, 2019; Revised February 10, 2020; Accepted February 25, 2020

Copyright $\odot 2020$ by authors, all rights reserved. Authors agree that this article remains permanently open access under the terms of the Creative Commons Attribution License 4.0 International License

\begin{abstract}
Educational strategies provide opportunities to create learning where students can collaborate with others (Education should be collaborative). This can be carried out through developing FSCL learning model. This research aimed to test the validity of the FSCL model product to instill the character values to junior high school students in Ponorogo Indonesia. The method used in this research was a research and development with three stages of preliminary study, product development and product testing. The validity data was taken from a validation sheet, namely: The validity of the FSCL model from aspects of the model and material was analyzed using the Likert scale. The research findings indicate that the application of the FSCL model is very feasible to instill the character values to junior high school students.
\end{abstract}

Keywords Model, FSCL, Character, Value

\section{Introduction}

This research aimed to design a collaborative learning model between schools and families to instill the character values to junior high school students in Ponorogo Indonesia. The design of the collaborative learning model is Family Supported Collaborative Learning (FSCL). The background of this learning design starts from the problem in the junior high school students in Ponorogo Indonesia who have weak characters of self-respect and tolerance [1]. FSCL is a collaborative learning model between the school and family. FSCL learning design in instilling character values to children was carried out by teachers in schools through religious education material and by parents in the family. This learning covers the affective and psychomotor domains. Good character education is education that teaches the good relationship between humans and God, between human beings, and between humans and the surrounding environment [2].

Character education is the internalization of values instilled in children so that they have other characteristics in virtue. [3] explained that in instilling character education in Indonesia, it is necessary to instill 6 pillars of noble characters, which should be used as references in character education both at school and outside of school, namely as follows: (1) Wisdom; (2) simplicity; (3) integrity; (4) bravery; (5) generosity and; (6) justice.

To instill character values in the family, it is necessary to identify character values because character education without identification of character values will only be a long endless journey. Therefore, every family in the world who pays a great attention to character education should identify character values that are the pillars of children's behavior in the family. These character values can be derived from the teachings of religion, philosophy and national culture, or the norms and values of local wisdom that apply in the community [4].

The etymological family comes from Sanskrit "kulawarga (family)", "ras (race)" and "warga (people)" which means "member" [5]. Meanwhile [6] a family is a group of people consisting of family members, many of whom can also come from the closest family environment that still has blood relations. A family, as the smallest social group, consists of several individuals, who have blood relations, bonds, obligations, and responsibilities among them. A family is the smallest unit of community consisting of the head of the family and several members who gather and live somewhere under a roof in a state of mutual dependence [7].

Philosophically, the family is the basic social unit of Islamic society. If Islam can be described as the soul of the Islamic community, the family can be seen, figuratively, as the body. For thousands of years, a family is the main focus of people's emotional, economic and 
political identities [8]. Changes that occurred in the $19^{\text {th }}$ century and especially the $20^{\text {th }}$ century weighed heavily on this unit, but families, along with the Islamic faith, remained central in the lives of people from all social classes, in the context of villages and cities, and in all Muslim countries

The concept of family has existed since the history of human life. Where there are humans, there must be families who give birth, care for and educate them even in a very short time. In the theological perspective [9], there are only two people born not from a family system, Adam as the first human male and Eve as the second human female. It was these two people that tried from the very beginning to develop the concept of the family at the direction of God. Adam and Eve made a kind of agreement and committed (mitsaqan galiza) to cooperate in meeting the needs of each other in terms of both biological and emotional needs

A family in the Islamic view [10] has a big value. Even Islam pays great attention to family life by laying out wise rules to preserve family life from disharmony and destruction. Why is Islam concerned so much? Because it is undeniable that the family is the first brick to build a Muslim community palace and is a religious madrasa (school) that is expected to be able to produce generations of Muslims who can elevate Allah's sentence on the face of the earth. If this foundation is strong, both the right religion and morality of the members, the community will also be strong. Thus, the desired security will be realized. On the other hand, if the family bond is broken, which poisons the family members, then the impact will be seen in the community because disastrous events occur. Thus, security is not obtained.

In Islamic teachings, children are the mandate of Allah. Mandate must be accounted for. Obviously, parents have a big responsibility on their children. In general, their main responsibility is to provide education for their children in the household. Allah commands: "Take care of yourself and your family from the torments of hell." (Q.S. At-Tahriim: 6). [11] The obligation can be carried out easily and naturally because parents really love their children. This is the human nature since birth. Humans are created with the nature of loving their children. "Riches and children are the life jewelry of the world". (Al-Kahf: 46). [11].

In his book [12], narrated from Anas bin Malik, Aisha had come to a mother with her two young children. She gave the woman three pieces of dates. The woman gave them to each of the woman's children and one for herself. They ate out the two dates, and then they turned to their mother. She split the dates in halves and gave each one to the two children. Suddenly, the Prophet Muhammad SAW came, and Aisha told him about it. Prophet Muhammad SAW said: "What makes you amazed from that occurrence? God has actually blessed her love and affection to her two children." The argument asserts that
(1) it is compulsory for parents to provide education in their households, and (2) it is natural because God creates parents to love their children.

The success of the family in instilling character values in children is very dependent on the type of parenting applied by parents to their children. Parenting can be defined as a pattern of interaction between children and parents which includes fulfilling physical and psychological needs, as well as norms that apply in society so that children can live in harmony with their environment. Some types of parenting according to [13] are: (1) Authoritarian parenting, characterized by the followings: parental power is dominant; children are not recognized as individuals; control of children's behavior is very strict; and parents punish children if they are not obedient; (2) Democratic parenting, characterized by the followings: there is cooperation between parents and children; children are recognized as individuals; there is guidance and direction from parents; and parents' control is not very strict; and (3) Permissive parenting, characterized by the followings: domination by children; loose attitude or freedom from parents; and very lack of parents' control and attention. Through parenting done by parents, children will learn many things including characters. This means that the type of parenting set by parents towards their children determines the success of their character education by the family.

Character learning in the family is a systematic effort to instill character values to children carried out by parents in the family, which includes components of knowledge (cognitive), feelings (affective) and actions (psychomotor) to carry out those values, to be good for God, the Almighty, themselves, fellow human beings, and the surrounding environment [14].

In the research of [15], it simplifies $21^{\text {st }}$ century education into four (4) principles as follows: 1). Instruction should be student-centered, meaning that the development of learning should use a student-centered learning approach. Students are placed as the learning subjects which actively develop their interests and potentials. They are no longer required to listen and memorize the subject matter given by the teacher, but try to construct their knowledge and skills, according to their capacity and level of development of thinking, while being invited to contribute to solving real problems that occur in society; 2). Education should be collaborative, which means that students must be taught to be able to collaborate with others who are different in their cultural background and values. In exploring information and making meaning, students are encouraged to be able to collaborate with their friends in their class. In working on a project, students need to be taught how to appreciate the strengths and talents of each person and how to take on roles and adjust themselves appropriately to them; 3 ). Learning should have context, meaning that learning will not be meaningful if it does not have an impact on the 
students' lives outside of school. Therefore, subject matter needs to be linked with their daily lives. The teacher develops learning methods that allow students to connect with the real world. The teacher helps students to find values, meanings and beliefs for what they are learning and can apply them in their daily lives. The teacher evaluates student's performance associated with the real world; and 4). Schools should be integrated with society, meaning that in an effort to prepare students to be responsible citizens, schools should be able to facilitate them to be involved in their social environment, e.g. holding community service activities, where students can learn to take roles and carry out certain activities in the social environment. Students can be involved in various development programs in the community, such as health, education, environment and so on. In addition, they also need to be invited to visit orphanages to train their sensitivity to empathy and social care.

Collaborative learning uses groups that help the learning system to remain in the traditional line classically. Cooperative learning is a simple sub-category of collaborative learning. Other authors state that cooperative learning is part of collaborative learning that uses a sensible approach. Cooperative learning is positioned as a continuum and cooperative structures become collaborative structures [16].

Collaborative learning aims to protect students from dependence on teachers who hold the authority of learning materials. The next is collaborative learning. [17] defines learning activities in groups are not always monitored by the teacher, but the teacher has a role and responsibility as a member during the process of seeking knowledge by students.

The essence of collaborative learning with cooperative learning harmoniously seeks solutions to learning material. The purpose of collaborative learning is to develop the ability to think on one's own and to reduce the character of idealism in cooperative learning. According to [18], the added values of collaborative learning are: (1) training caring, attention, and willingness to share; (2) increasing respect for others; (3) training emotional intelligence; (4) prioritizing groups above personal interests; (5) sharpening interpersonal intelligence; (6) training the ability to work together; (7) training listening to others' opinions; (8) overcoming conflict management; (9) training the communication skills; (10) not being ashamed to ask their own friends; (11) increasing the learning speed and outcomes; (12) increasing memory of the material being studied; and (13) improving motivation and learning atmosphere.

The advantages of collaborative learning include: 1) Collaborative learning is more effective than individual learning [19]-[22]; 2) Learning outcomes of collaborative learning are higher than those of individual learning [23], [24]; 3) Collaborative learning increases student motivation [25]; 4) In general, collaborative learning groups become interactive learning environments that are important for students to explore making meaning of learning concepts together and developing knowledge by encouraging interpersonal interaction, information sharing, and exploration [24], [26], [27]; 5) Collaborative learning groups build collective representation and transform this representation to produce specific results that arise from interactions between individual cognitive schemes and interaction patterns in groups [24], [28].

Then, the disadvantages of collaborative learning according to [18] are as follows: (1) Smarter students will feel very disadvantaged if they do not understand the real purpose of this process; (2) They will object because the value obtained will be determined by the achievements of the group; (3) If cooperation cannot be carried out properly, only a few smart and active students will work.

The conceptual learning of FSCL is to develop learning in the character education subject, namely Islamic religious education (PAI) that uses learning with the collaborative model. The collaborative model used in junior high schools in Ponorogo is the 5E learning cycle developed with the following steps: a) Engage, the involvement of students in the learning process with activities, among others: the teacher focuses students' attention, arouses their interest, motivation, and curiosity about the material which will be studied; the teacher facilitates students in exploring initial knowledge through giving questions or problems related to the material to be studied; b) Warok, a learning content in the family. This means that the development of character education carried out by teachers in schools must be collaborated with education in the family by doing some teaching called "Warok" with the following steps: $\mathrm{W}=$ Wani (Brave), $\mathrm{A}=$ Anulodho (Giving example), $\mathrm{R}=$ Rumekso (Caring), $\mathrm{O}=$ Omber (Expanding), $\mathrm{K}=$ Kulino (Habit); c) Explore, with support from the family, learning in the school is continued with exploration with the following steps: The teacher distributes worksheets and gives a problem to be solved by students; The students form groups to discuss issues raised by the teacher and find solutions/answers to these problems, do practicum, test hypotheses, and collect the data/information; The teacher acts as a facilitator providing guidance as needed to students; d) Explain, the explanatory stage include: The students conduct group discussions to analyze data/ information collected from activities in the previous phase; They explain the concepts, information, knowledge they obtain from activities in the previous phase using their own words; The teacher provides clarification on the results of student discussions and helps students to rediscover lost information or replace the wrong information with new ones; e) Elaborate, this stage includes: Students apply concepts, information, knowledge, and skills that they acquired in the previous phase into new situations or problems whose solutions require identical or similar explanations; They apply their understanding of concepts by carrying out 
additional activities; f) Evaluate, in this learning process the evaluation is carried out by the teacher with the following activities:

The teacher makes feedback by recalling students' ideas, knowledge or skills that have been learned. Collecting feedback is done to find out how far students understand the topics they have learned; The teacher conducts evaluation/assessment of learning outcomes.

\section{Materials and Methods}

This study used the quantitative method based on the philosophy of positivism, which is used to examine certain populations and samples using research instruments to collect the data analyzed quantitatively and statistically with the aim of testing the predetermined hypothesis [29]. This research was conducted in junior high schools in Ponorogo, with the research subjects of the students of SMP 1 Ponorogo, SMP 6 Ponorogo, and SMP Babadan Ponorogo. The object of this research was the FSCL learning model to improve student's character.

The testing procedure in this research includes alpha testing, namely media expert validation, material expert validation, trial of instrument items in the form of instrument validity and reliability tests, and beta testing, which is product usage test. The data were collected using questionnaires.

The technical data analysis used in this research was the quantitative data analysis technique. The assessment data obtained from the validators were analyzed qualitatively and used as a reference for revising the product to produce a feasible product. The results of the assessment of all aspects were measured with the Likert scale. Likert scale is several positive or negative questions regarding an object of attitude. The main principle of the Likert scale is to determine the location of one's position in a continuum of attitudes towards the object of attitude ranging from very negative to very positive [29]. Then, the percentage of the results can be calculated using the following formula:

$$
\text { Hasil }=\frac{\text { total skor yang diperoleh } \mathrm{h}}{\text { skor maksimum }} \times 100 \%
$$
[30]

Feasibility categories are based on the following criteria

Table 1. Feasibility criteria for the learning model

\begin{tabular}{|l|l|l|}
\hline No & Score $(\%)$ & Feasibility Category \\
\hline 1 & $<21 \%$ & Very infeasible \\
\hline 2 & $21-40 \%$ & Infeasible \\
\hline 3 & $41-60 \%$ & Quite infeasible \\
\hline 4 & $61-80 \%$ & Feasible \\
\hline 5 & $81-100 \%$ & Very feasible \\
\hline
\end{tabular}

The research data were obtained from the results of filling out a set of instruments in the form of questionnaires given to two learning model experts, two material experts and several respondents to assess the results of validity from the Family Supported Collaborative Learning (FSCL) model developed. The results of the validation by the model experts in the form of the results of responses and assessments were analyzed and revised according to the recommendations of the product. The data are shown in Figure 1.

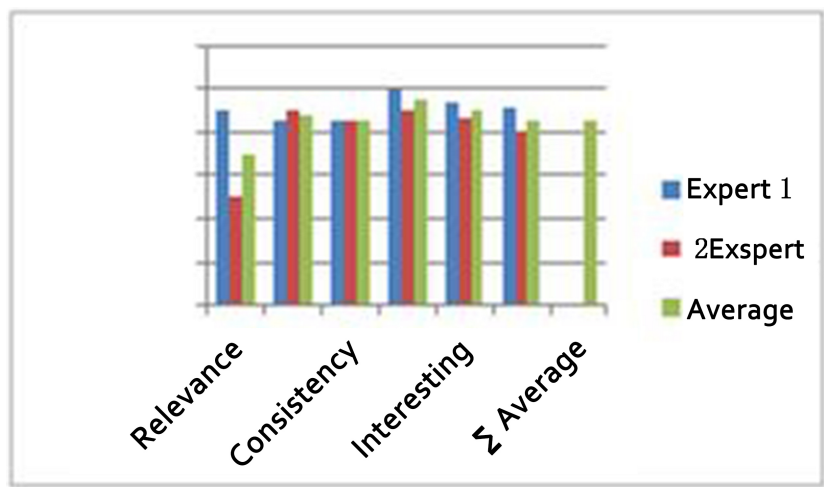

Figure 1. Bar chart of the percentage from learning model experts

Figure 1 shows that the feasibility percentage in terms of the relevance aspect of the two experts scored an average of $70 \%$. Based on the language aspect, the average score is $87.50 \%$. The consistency aspect has an average score of $85 \%$. The pedagogy aspect has an average of $95 \%$. The interesting aspect obtained an average of $90 \%$. The total percentage of all aspects obtained from the two experts is $85.50 \%$. Thus, the FSCL learning model is categorized as very feasible to use.

The results of the validation by material experts in the form of the results of responses and assessments from material experts were analyzed and revised according to the recommendations of the product. The data are shown in Figure 2.

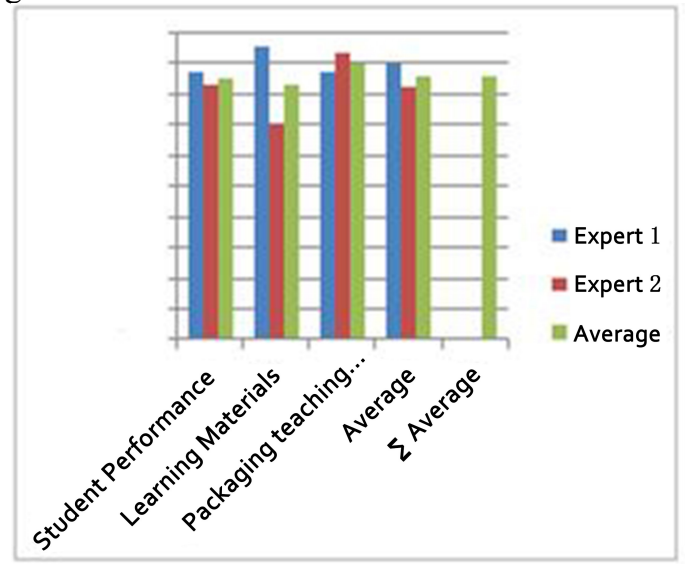

Figure 2. Bar chart of the percentage from material expert

Figure 2 shows that the percentage of validity in terms of the student performance aspects of the two material experts averaged $85 \%$. Based on the learning material aspect, the average score is $82.50 \%$. The packaging aspect of teaching materials obtains an average of $90 \%$. From all 
aspects obtained from the two material experts, the average score is $85.83 \%$, which means that the learning material of FSCL is very feasible to use.

The validity test was carried out with an instrument trial on students of SMPP 6 Ponorogo. Then, the data obtained were analyzed using product moment correlation techniques using Ms. Excel application to determine the validity of each instrument before used for the trial. The results of the validity can be seen in Table 2 .

Table 2. Calculation results for instrument validity

\begin{tabular}{|c|c|c|c|}
\hline Item & $\mathrm{R}$ & $\mathrm{R}$ table & Remark \\
\hline 1 & 0,513 & 0,361 & Valid \\
\hline 2 & 0,728 & 0,361 & Valid \\
\hline 3 & 0,555 & 0,361 & Valid \\
\hline 4 & 0,580 & 0,361 & Valid \\
\hline 5 & 0,606 & 0,361 & Valid \\
\hline 6 & 0,590 & 0,361 & Valid \\
\hline 7 & 0,578 & 0,361 & Valid \\
\hline 8 & 0,700 & 0,361 & Valid \\
\hline 9 & 0,589 & 0,361 & Valid \\
\hline 10 & 0,473 & 0,361 & Valid \\
\hline 11 & 0,503 & 0,361 & Valid \\
\hline 12 & 0,544 & 0,361 & Valid \\
\hline 13 & 0,762 & 0,361 & Valid \\
\hline 14 & 0,680 & 0,361 & Valid \\
\hline 15 & 0,650 & 0,361 & Valid \\
\hline 16 & 0,657 & 0,361 & Valid \\
\hline 17 & 0,404 & 0,361 & Valid \\
\hline 18 & 0,463 & 0,361 & Valid \\
\hline 19 & 0,410 & 0,361 & Valid \\
\hline 20 & 0,710 & 0,361 & Valid \\
\hline
\end{tabular}

In this research, the reliability test was conducted using internal test. The internal consistency test was carried out by testing the instrument once. Then, the data obtained were analyzed with certain techniques. The results of the analysis can be used to predict instrument reliability. The reliability test was performed using alpha formula.

$$
\begin{gathered}
r i=\frac{k}{(k-1)}\left\{1-\frac{\in \sigma b 2}{\sigma t 2}\right\} \\
r i=\frac{20}{(20-1)}\left\{1-\frac{9,45}{64,32}\right\} \\
r i=0,898
\end{gathered}
$$

Thus, from the calculation of 0.898 based on the table of interpretation of the $r$ value, the reliability of the instrument belongs to the high category. Thus, the instrument can be trusted to be used for the usage test.

\section{Conclusions}

The research findings indicate that the application of the FSCL model is very feasible to instill the character values to junior high school students.

\section{Acknowledgments}

First of all, thanks to Allah SWT for giving us blessings, mercy and health that we can accomplish this article, Secondly. We would like to thank the Ministry of Religion of the Republic of Indonesia for providing funds to the author through the Decision Number: 4006/Dj.I/Dt.I.IV/ PP.04/10/2018 about the awardee of research assistance to improve the quality of educators and educational staff in the Ministry of Religion and Doctoral Program (S3).

\section{REFERENCES}

[1] J. Budiwan, F. Hidayatulloh, and A. Yusuf, Munawir, "The profile of the public junior high school students' character values in Ponorogo," Procceding Iconsme, vol. 5, no. x, p. 243, 2018.

[2] Amirulloh Syarbini, Model pendidikan karakter dalam keluarga. Jakarta: PT Gramedia, 2013.

[3] Mira Mirawati, "Peran keluarga dalam membangun karakter anak usia dini,” J. Univ. Pakuan, pp. 11-23, 2017.

[4] M. Boorba, "Membangun kecerdasan moral," in Membangun kecerdasan moral, Jakarta: Gramedia Pustaka, 2008, p. 19.

[5] Widharyanto, Kamus Pepak Basa Jawa. Yogyakarta: Konggres bahasa jawa Yogjakarta.

[6] KBBI, Kamus besar bahasa Indonesia, Ketiga. Balai Pustaka, 2005.

[7] Koentjoroningrat, Antropologi Sosial. Jakarta: Dian Rakyat, 1997.

[8] P. Vermeer, "Religion and Family Life: An Overview of Current Research and Suggestions for Future Research," Religions, vol. 5, no. 2, pp. 402-421, 2014.

[9] Zakiah Darajat, "Pendidikan islam dalam keluarga dan sekolah,” Jakarta: Bumi Aksara, 2012.

[10] M. N. Musharraf and F. B. Nabeel, "Schooling Options for Muslim Children Living in Muslim-Minority Countries A Thematic Literature Review," ISSNPrint) Int. J. Soc. Sci. Humanit. Res. ISSN, vol. 3, no. 4, pp. 2348-3156, 2015.

[11] Qurais Shihab, Tafsir Al-Mishbah. Jakarta: Lentera Hati, 2001.

[12] Imam an-Nawawi, Riyadhus shalihin. Jakarta: Pustaka Imam Asy-Syafii jilid 1-5, 2012.

[13] J. W. Santrock, Educational Psychology: Fifth Edition. 
Dallas: McGraw-Hill, 2016.

praktek. Jakarta: Rienika Cipta, 2005.

[14] S. Muttha, "Peace, Moral and Value Education'Mulyavardhan': An Innovation for Social Transformation," vol. 4, no. 3, pp. 231-242, 2012.

[15] J. R. Nichols, "Four Esensial Rules of $21^{\circ}$ Century Learning,",

Http://www.teachthought.com/Learning/4-esential-rules-of -21 st-century-learning/, p. 38, 2017.

[16] Elisabert E Barkley, Collaborative Learning Technique. San Fransisco: Jossey-Bass, 2016.

[17] Bruffee, "Collaborative Learning." Sain Luis College Publiser, Missouri, p. 15, 1999.

[18] Gunawan A.W, Genius learning strategy. Jakarta: Gramedia Pustaka, 2006.

[19] K. R. Wentzel and D. E. Watkins, "Peer Relationships and Collaborative Learning as Contexts for Academic Enablers," Sch. Psychol. Rev., vol. 31, no. 3, pp. 366-377, 2002.

[20] F. Pattanpichet, "The Effects of Using Collaborative Learning to Enhance Students' English Speaking Achievement," J. Coll. Teach. Learn., vol. 8, no. 11, pp. 1-10, 2011.

[21] H. J. Yazici, "Student Perceptions of Collaborative Learning in Operations Management Classes," J. Educ. Bus., vol. 80, no. 2, pp. 110-118, 2004.

[22] B. Havard, J. Du, and J. Xu, "Online collaborative learning and communication media," J. Interact. Learn. Res., vol. 19, no. 1, pp. 37-50, 2008.

[23] H.-Y. Sung and G.-J. Hwang, “A collaborative game-based learning approach to improving students' learning performance in science courses," Comput. Educ., vol. 63, pp. 43-51, 2013.

[24] I. Reychav and R. McHaney, "The relationship between gender and mobile technology use in collaborative learning settings: An empirical investigation," Comput. Educ., vol. 113, pp. 61-74, 2017.

[25] P. L. Curşeu and H. Pluut, "Student groups as learning entities: The effect of group diversity and teamwork quality on groups' cognitive complexity," Stud. High. Educ., vol. 38, no. 1, pp. 87-103, 2013.

[26] P. Dillenbourg, "What do you mean by collaborative learning?" in Collaborative-learning: Cognitive and Computational Approaches, P. Dillenbourg, Ed. Elsevier, 1999, pp. 1-19.

[27] S. Volet, M. Summers, and J. Thurman, "High-level co-regulation in collaborative learning: How does it emerge and how is it sustained?" Learn. Instr., vol. 19, no. 2, pp. 128-143, 2009.

[28] P. L. Curşeu, S. Schruijer, and S. Boroş, "The Effects of Groups' Variety and Disparity on Groups' Cognitive Complexity,” Gr. Dyn., vol. 11, no. 3, pp. 187-206, 2007.

[29] Sugiono, "Metode penelitian kombinasi," in Metode penelitian kombinasi, Bandung: Alfabeta, 2016, p. 35.

[30] Suharimi Arikunto, Prosedur penelitian suatu pendekatan 